\title{
Evaluating motivational characteristics in vocational music education within the perspective of self-determination theory
}

\author{
Esa Virkkula* (10)
}

${ }^{*}$ Correspondence: esa.virkkula@oamk.fi Oulu University of Applied Sciences, Yliopistonkatu 9, 90570 Oulu, Finland

\begin{abstract}
This article examines the influence of vocational music education workshops on the learning motivation of popular and jazz music students in a self-determination theory's (SDT) framework. SDT illustrates that satisfying people's universal psychological needs has a significant influence on well-being and learning. Psychological needs will become satisfied when the learner autonomously influences the choices and decisions of his or her learning. The learner feels then competent to act in the learning environment and receive the experiences related to it. The present article is based on a qualitative research project that examined 62 Finnish conservatory popular and jazz music students who participated in 11 music performance workshops with professional musicians in 2003-2011. The research data consists of (a) workshop plans and learning goals written by the students before the workshops and (b) reflective essays of experiences after the workshops. The data was analysed using theory-oriented content analyses. The students were responsible for the planning and implementation of music performances with professional musicians. Commitment to challenging performance projects with professional musicians motivated the students to try their best to develop their musicianship.
\end{abstract}

Keywords: Autonomy, On-the-job learning, Motivation, Music education, Vocational education

\section{Introduction}

To become a professional musician requires years of determined work in order to reach sufficient skills and knowledge. The student faces many challenges on the way to professionalism (MacIntyre et al. 2018; Evans and Bonneville-Roussy 2016; Gaunt 2011). For this reason, it is important for a music teacher to consider what kind of learning environments support student motivation and contribute to the development of competence (Barrett and Bond 2014; Cogdill 2014).

In several of the recent music education research reports (e.g. Countryman 2014; Evans and Bonneville-Roussy 2016, Evans et al. 2013; Gonzalez-Moreno 2012; Küpers

(c) The Author(s) 2020. This article is licensed under a Creative Commons Attribution 4.0 International License, which permits use, sharing, adaptation, distribution and reproduction in any medium or format, as long as you give appropriate credit to the original author(s) and the source, provide a link to the Creative Commons licence, and indicate if changes were made. The images or other third party material in this article are included in the article's Creative Commons licence, unless indicated otherwise in a credit line to the material. If material is not included in the article's Creative Commons licence and your intended use is not permitted by statutory regulation or exceeds the permitted use, you will need to obtain permission directly from the copyright holder. To view a copy of this licence, visit http://creativeco mmons.org/licenses/by/4.0/. 
et al. 2014; Leung and McPherson 2011; MacIntyre et al. 2018), the authors have examined the factors which make students motivated in their music studies. What factors make studying meaningful and interesting and which kinds of action can trigger the development of motivation (e.g. Pintrich 2003)? These questions have been covered well in literature, with motivation proving to be a significant factor in attaining outcomes in learning (Wigfield and Cambria 2010). Being motivated has been defined as the energy of learning that manifests itself as goal-oriented action and good achievements (Deci and Ryan 2000; Pintrich and Schunk 2002). Although the importance of motivation in learning has long been studied, it is still an interesting theme of research in music education.

During recent years self-determination theory (SDT) has proved to be one of the most significant motivation theories. It deals with areas of human well-being and has been used, for example, for the research of domains such as education, working life and sports (Deci and Ryan 1985, 2000, 2014, 2017).

\section{Self-determination theory}

The present study will clarify the learning motivation factors of popular and jazz music students in conservatories according to the self-determination theory (SDT) (Deci and Ryan 1985, 2000, 2014, 2017). It relates to motivational theory, as illustrated in several research reports (e.g. Lam and Gurland 2008; Reeve 2004; Roca and Gagné 2008). SDT introduces satisfied universal psychological needs as the prerequisite of people's wellbeing and, on the other hand, highlights the importance of optimal action in learning environments. Deci and Ryan $(2000,68$, also 2014, 14-16) focuses on the fact that an individual has a psychological need to be allowed to determine autonomously the decisions and choices concerning him/herself, the need to be competent in acting in his/her habitat and, on the other hand, the need to feel relatedness to his/her community.

Interaction between an individual and the environment, according to Deci and Ryan (2014, p. 16), holds an important position in satisfying psychological needs. An individual will either be satisfied or not in the social context: the more satisfied an individual is, the more contented the individual is. If satisfying the needs is thwarted, the more discontented the individual is. From the perspective of learning, it is significant that the learner feels autonomous, as he/she can then experience the ownership of his/her learning process. Motivation is maintained and deepened if the learning environment makes it possible to work towards autonomy (Reeve et al. 2012).

In SDT, the factors illustrating learning motivation can be observed from the perspective of both the individual and the environment (Renwick and Reeve 2012). Seen from the individual's point of view, learning motivation is typically approached by dealing with the relationship between autonomous and externally controlled learning. Deci and Ryan (2014, p. 28) sum this up: "the theory postulates that when people's basic psychological needs are satisfied they are more autonomously motivated to work, and when their basic needs are thwarted they are controlled or amotivated".

In educational research Reeve (2004, p. 186-188, also Reeve et al. 2012) examined the differences between guidance supporting autonomy and guidance controlling learning from an individual point of view. Autonomy-supporting guidance was based on listening to student, involving him/her in planning the learning processes, and encouraging to work autonomously and to take responsibility. The teacher guided the student with 
questions and encouraging feedback, while in the guidance to control learning, the teacher gave directives, expressing "you should, must and have to" statements and ready solutions without the student gaining the opportunity to find solutions for him/herself. Moreover research (Reeve 2004, p. 188) showed that the student understood the items that needed to be learnt more meaningfully if the teacher did not act in a controlling way. A student's strong involvement in the learning process had a positive connection to learning motivation.

Respectively in music education research setting Küpers et al. (2014) employed the SDT in a study concerning instrumental learning. Musical development was observed to be a dynamic process in which the scaffolding in learning and SDT were deeply intertwined. In the model developed by the researchers, the teacher reduced the use of direct guidance with increasing student skill, through which the responsibility moved gradually to the student. Learning changed stepwise from teacher-regulated to self-regulated action (cf. Grow 1991). From the perspective of SDT, the focus is on supporting learning autonomy according to the growth in competence.

The aforementioned studies showed the importance of the music student's own sense of autonomy to his/her motivation (cf. Deci and Ryan 2017, 2014). SDT does not, however, merely illustrate motivation from the perspective of differences in the characteristics of individual students but stresses the influence of the learning environment. We can speak of environment-centred observation. The development (or, indeed, the underdevelopment) of learning motivation is connected to the quality of the interaction between the individual and the environment that promotes learning. The tutor-learner relationship can thus both promote the learner's motivation and act as an obstacle to motivational development, in which case the student becomes frustrated and even quit his/her studying (Renwick and Reeve 2012).

Evans et al. (2013) examined high-school students' decisions to quit studying from the perspective of psychological needs. The music students who had studied for at least ten years expressed how their decision to quit was connected to the feelings of decrease in autonomy, competence and relatedness-their psychological needs were not satisfied. The researchers (Evans et al. 2013, p. 613-614) recommended that teachers should plan their lessons to be optimally challenging by giving the students the chance to acquire new skills that generate the experience of competence. Social interaction appeared to be an important part of music studies. Students' active participation in communal action, as a peer among peers, strengthened their feelings of relatedness. In addition, from the perspective of motivational development, it appeared important for the students to be allowed to influence the content and implementation of studies to support autonomy.

As a summary we can state that the satisfaction of a music student's needs, viz. the sense of autonomy, the feel of relatedness and the enjoyment produced by music, is a significant contributor to motivation (Hallam 2011, p. 278). Hallam (2011, p. 286) continues, "research needs to focus more closely on what it is about music, which provides enjoyment and satisfaction". Additionally, there also seems to be "a need for research exploring issues of motivation in different learning contexts" (Hallam 2009, p. 291).

This study is connected to the research field described above by evaluating the motivational characteristics of popular and jazz music students in the conservatory. In music education studies, less attention has sometimes been given to evaluating the 


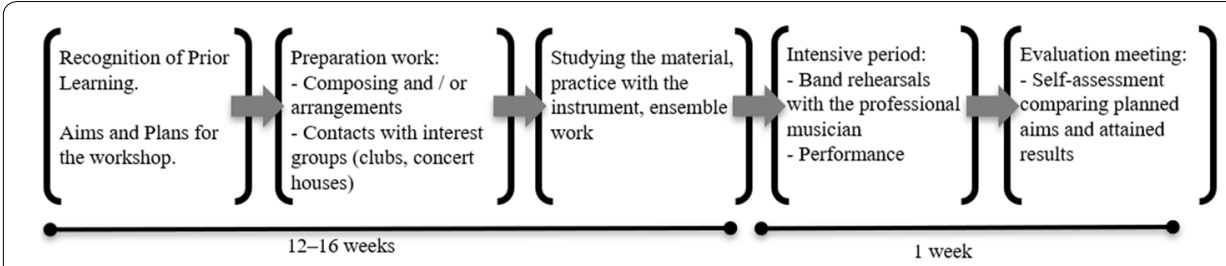

Fig. 1 The steps of progress in the workshops

motivational characteristics of music students who aim at becoming professional musicians. The students are readily interested in music and are relatively skilful. On the other hand, attaining and maintaining professional competence requires continuous commitment in terms of developing one's competence (Hallam 2011, Renwick and Reeve 2012). The study was conducted as a qualitative case study to enable music students to describe their feelings about the satisfaction of universal psychological needs in their studies.

The researcher first built a learning environment-a workshop in which the students' universal psychological needs were first paid attention to according to the principles of the SDT. Next, a research question was set to focus on how the cooperation of a professional musician and conservatory students is in connection to the students' learning motivation evaluated in the perspective of self-determination theory?

\section{Research context}

Conservatories in Finland belong to publicly funded educational organizations that offer three-year full-time studies for the upper secondary vocational qualification in music (180 credits). In vocational education, attention has been paid especially to the development of cooperation between work life and educational units in "learning at work"(Jokinen et al. 2009).

Learning at work is a significant part of vocational education and training. It means that the student learns qualification objectives in authentic working situations throughout his/her studies. Learning at work is individually planned, must be sufficiently broad and versatile from the point of view of mastering the profession. In the field of music, learning at work means the student's action in terms of a musician's tasks: preparing the pieces of music for performances, practising music individually, ensemble work, arranging and implementing performances (FNAE [Finnish National Agency for Education] 2014). Carrying them out requires strong motivation: commitment, and responsible and initiative action in an ensemble.

In this research project, the musicians' vocational learning at work was arranged in a new type of workshop in which the students planned and implemented a performance in cooperation with professional musicians ${ }^{1}$ according to popular and jazz music tradition (see Berliner 1994, p. 44-45, also Gatien 2009; Gridley 2003). The study consisted of 11 workshops as part of the vocational education of 62 students aged from 17 to 24 years in the Conservatory of Oulu, Finland, in 2003-2011.

\footnotetext{
${ }^{1}$ One professional musician per workshop, a total of eleven musicians was involved.
} 
At the beginning of the workshop (see Fig. 1), the participants cooperatively planned the theme of music and chose the pieces to be played. In the planning phase, the students' musical competences were observed and, on the other hand, their needs in terms of learning new things were to be met through workshop action. After cooperative planning, the students wrote their personal workshop plans and learning goals on the form. Next, they started preparing the music to be played: composing/arranging music, instrumental and ensemble practising and making contracts for the performances with a concert house or a music club. The students worked autonomously, but were given guidance from their instrumental teacher, and in their ensemble work from the teacher who was responsible for that matter.

The final intensive period of one week was started on a Monday with a joint practice between the professional musician and the students. During the intensive period, they worked typically $6-7 \mathrm{~h}$ a day. The workshop culminated in a performance followed by a cooperative evaluation discussion among the participants. Finally, the students reflected on their workshop experiences on a structured form.

This research is a continuation of an earlier workshop project from the perspective of sociocultural learning in communities of practice (Virkkula 2016a). The previous research results showed that the workshop corresponds to the features of community of practice. Workshops offer many levels of learning to develop musicianship, which then gives rise to recognizing the potential of sociocultural learning in music schools and developing learning environments according to the model of communities of practice.

The second part of the research studied informal learning in workshops, which is typical of those who perform popular and jazz music. The research demonstrated that conservatory education would benefit when allowing students to cooperate in authentic working life projects. It is advisable to take into consideration the ways in which music is learnt outside of formal education (Virkkula 2016b).

Problem solving skills are a keystone in professional competence. The mission of musicians' education is to prepare the student to meet the challenges of the future profession and find appropriate solutions to them (FNAE 2014). In the third part of the present research project, the problem solving processes of music students and engineers were examined from the perspective of problem-based learning, PBL (Nissilä and Virkkula 2015). Both groups benefited from solving problems connected to their work tasks by using systematic methods. The key to successful implementation of PBL lies in designing a learning environment that stimulates students towards self-directed, collaborative, and contextual learning as well as consistency in or alignment between all aspects of the curriculum, such as the problems used, the tutors' guidance, and the assessment employed.

One of the spearhead projects in the Finnish education today is learning to learn. On the fourth part of the research project the researchers focused on learning strategies which have been examined from a variety of perspectives (Virkkula and Nissilä 2017). Direct and indirect learning strategies formed the model of defining music students' self-assessed learning habits in this research. The strategies dealt with were memory, cognitive, compensation, metacognitive, affective and social strategies. Critical thinking strategies as well as deep and surface learning strategies were also observed.

To widen understanding of learning in workshops, one researcher participated in a workshop as a musician in the fifth part of the research and played in an ensemble 
with his teacher colleagues and professional musicians (Virkkula and Nissilä 2014). In the research results of this participant observation, the significance of musicians' shared interactions with learning was perceived. On the other hand, the researcher's personal experience of the workshop offered a wider perspective than merely analysing the written research data produced by the students.

\section{Research method, data and analysis}

This qualitative case study describes and evaluates the effectiveness of a case-the workshop method-on student learning. More specifically, the aim of the study is to increase understanding of the connections between the workshop work and students' learning motivation. The researcher ended up with the qualitative research strategy and open questions in order to be able to examine the students' individual senses emphasized by self-determination theory during the cooperation with a professional musician (Deci and Ryan 2014).

The research follows the method typical of case studies: it looks for an in-depth explanation of the social phenomenon existing in a real-world context (Yin 2013, p. 16, also Stake 1995). The context in this connection refers to the environment where the events of the case are realized, not referring to an artificial experimental setting.

Swanborn (2010, p. 1-5) presents a case framework that makes it possible for the researcher to deal with the theoretical conceptions and results of empirical findings, as connected to the case. A unique study target is observed in a versatile way, often from the perspective of the participants (e.g. students). The research process often focuses on the experiences of the participants and their descriptions.

In a case study, the data is collected in different ways, e.g. through written questionnaires, participating observations, through interviews and collecting from archive material and documents (Stake 1995; Yin 2013).

\section{Data}

In this research, the data was collected and analysed in three phases. At the beginning of workshop work (phase 1), students $(\mathrm{N}=62)$ wrote their structured workshop plans in which they outlined their learning goals. Writing the plan proceeded under the guidance of the following questions: "How did you participate in preparing the workshop?", "Describe the theme of the workshop, for instance its music genre", "How do you intend to prepare for the workshop?", "What would you like to learn in workshop work?" and "What other expectations do you have concerning workshop work, the professional musician and the workshop concert?"

After the workshop (phase 2), the students $(\mathrm{N}=62)$ wrote about their experiences of the workshops guided by the following questions: "Describe your cooperation with the professional musician", "What did you learn in the workshop?" and "What could you have done in another way?" Additionally, the students responded to multiple-choice questions by choosing one of the given options (five-point Likert scale). The questions were "How did the workshop correspond to your idea of the musician's work?" and "Are the skills gained from workshops adaptable in the work life of a musician?" 


\section{Analysis}

The researcher analysed the study data produced by the students (phase 3) using a theory-oriented content analysis method, which is widely used for systematic analyses of diverse data in qualitative research (Schreier 2012, p. 2-5). Its basic principle is to arrange the data so that it can be used for clear descriptions of the data according to the theory. The research question defines the actual analysis that is typically undertaken on the text that the respondents have written or on their interviews that were transcribed (Schreier 2012, p. 4).

The content analysis proceeds from becoming familiar with the texts written by the respondents to the reduction of the expressions, after which the data is grouped according to similarities and differences. In the grouping of theory-oriented content analysis, some theoretical or conceptual system will be employed and used for tabulating the data. The basis of the analysis is thus formed by some theoretical aspect that is justified from the perspective of the research and directs the examination of the data (Marshall and Rossman 2011).

In this research, the data was transcribed, after which the grouped textual expressions were tabulated into the categories describing SDT. For tabulation, the students' written expressions were divided into categories according to the supported or unsupported autonomy, competence and relatedness (Deci and Ryan 1985, 2000, 2014). For example, the following text contains two expressions, and it represents the SDT-category 'supported autonomy' (no. 1): "I reflected and chose the pieces to sing myself. I practised the pieces on my own and with the band." One expression could represent only one category. The six categories used in the tabulation were: (1) supported autonomy, (2) supported competence, (3) supported relatedness, and (4) non-supported autonomy, (5) non-supported competence and (6) non-supported relatedness.

Aided by tabulation, the researcher could survey the data in student-specific, workshop-specific and SDT-specific ways and also collect quantitative data out of the data. The answers to the multiple-choice questions complemented the result. However, the study cannot be described as a mixed-method type, since quantitative data has only a supporting role (Creswell and Plano Clark 2011, p. 4-5, Teddlie and Tashakkori 2011, p. 285-286).

In the earlier parts of this research project, the data was also obtained by participant observation. The researcher's personal experiences and their analysesconcerning the work of a musician widened the understanding of learning in workshops (Virkkula and Nissilä 2014). In addition, various other researchers were involved in the earlier mentioned parts of the research project, and they offer a wider approach to the theme in question (e.g. Cohen et al. 2007).

\section{Results: Self-determination theory in workshops}

The students described the workshop work as action resembling the contents of SDT. The majority of written expressions referred to autonomous learning, professional competence and supported relatedness (88.6\%). Only slightly more often than in one tenth of the answers did the students describe workshop work as non-supported (see Table 1). 
Table 1 Research data classification

\begin{tabular}{lcl}
\hline $\begin{array}{l}\text { Self-determination theory category (Deci } \\
\text { and Ryan 1985, 2000, 2014). }\end{array}$ & $\begin{array}{l}\text { Expressions in total (Frequency } \\
\boldsymbol{F = 3 4 1 )}\end{array}$ & $\begin{array}{l}\text { Per cent of total } \\
\text { expressions } \\
(\boldsymbol{F} \% \mathbf{\%}=\mathbf{1 0 0})\end{array}$ \\
\hline Supported autonomy & 133 & 39.0 \\
Supported competence & 110 & 32.3 \\
Supported relatedness & 59 & 17.3 \\
Non-supported autonomy & 23 & 6.7 \\
Non-supported competence & 15 & 4.4 \\
Non-supported relatedness & 1 & 0.3 \\
\hline
\end{tabular}

\section{Autonomy in workshop learning}

In their written expressions, the students referred to three key areas of supported autonomy in learning according to SDT $(f=133, \mathrm{f} \%=39 \%)$ : (1) the students participated in the planning of the learning process, (2) they worked autonomously and responsibly, and (3) guidance in the workshop was based on encouraging feedback (see Deci and Ryan 1985, 2000, 2014, Reeve 2004, p. 186-188, also Reeve et al. 2012).

The students had a remarkable role in planning and preparing the repertoire for the concert. They reflected on the musical theme of the workshop, chose pieces and undertook all the necessary composing and arrangement tasks. The inclusion of the students from the outset also made them set concrete learning goals.

I reflected and chose the pieces to sing myself. I practised the pieces on my own and with the band. (I want to learn) the phrasing and improvisation typical of jazz singing (...) interesting new views on jazz and jazz singing and communicative ensemble playing under the guidance of a good mentor (professional musician). (A47)

We thought over the arrangements of the pieces together (with the band) and practised playing them. (...) I want to learn to play modern jazz as much according to the style as possible. I expect an easy-going time and the joy of experiments. (A36)

During the summer, I made myself familiar with a part of the practised material and prepared a composition of my own. (...) (I want to learn) different expressions of modern jazz, learn about the pieces from the theoretical point of view and the composing techniques used in them. To develop mastery and expression of my own instrument. To acquire deeper knowledge of modern jazz music (...). (A19)

The students' written expressions show how the workshop guided autonomous working, which required taking responsibility for the preparations for performances. Committed working was part of the acting method of the workshop.

(I prepared myself) by listening to and practising the pieces to be played in the gig with the ensemble and in my own time. I want to learn to play Hendrix and rock in general, "right" according to the style. (A40)

(I prepared) by composing and arranging a piece of my own. By training with the repertoire and improvisation. (A16) 
(The musical) material was really challenging and you had to work hard on it to survive (...). (A19)

The professional musicians who played with the students in the workshops appeared to be inspiring co-partners in ensembles. The guidance from the experienced musician was seen as encouraging and evidently included only a few directives. The students expressed how working with professional musicians was meaningful.

(The professional musician) was able (in the workshop) to break free from playing schematic approaches and made my motivation towards music greater than ever.

It was really great to work with visiting musicians. They were able to give both positive and constructive feedback of the things that could be improved (...) they treated us students as "colleagues". (A35)

The mentor (professional musician) didn't give as much feedback as I had wished for, but on the other hand, in that way he confirmed that students became active in listening to themselves. (A47)

Some of the written expressions $(f=23, \mathrm{f} \%=6.7 \%)$ revealed that workshop work did not always support the autonomy of the learners. In some workshops, student participation in the planning of the workshop had been scarce.

I didn't participate in the choice of the pieces. Chick Corea's music was not familiar beforehand (...) I was not informed enough (of the repertoire). (A1)

I didn't influence (the repertoire). I would have liked to participate in planning the theme of the workshop. (A2)

Everything was brought to me without asking my opinion, e.g. the pieces to be sung had already been chosen. It would have been nice to be able to participate in choosing the pieces. (A5)

\section{Competence in workshop learning}

In the written expressions that refer to supporting the competence of acting as a musician $(f=110, \mathrm{f} \%=32.3 \%)$, the students described the connections of the workshop in terms of learning to play, clarifying the structures of music, the development of self-confidence and the mutual communication of the players.

When "new" things are dealt with in practice (in the workshop) immediately, they will be learnt much faster. And at once in music. The level of playing skill is raised remarkably in a workshop of even a few days. (A2)

In the beginning, I was dubious of my ability to perform the large vocal ranges and also the stylistically different songs. Still I went through the challenges to victory, and it felt really fine. I learnt again to believe in my abilities throughout the workshop and, in fact, concentration and practise ensured the successful result. (A23) 
How did the workshop correspond to your idea of the musician's work?

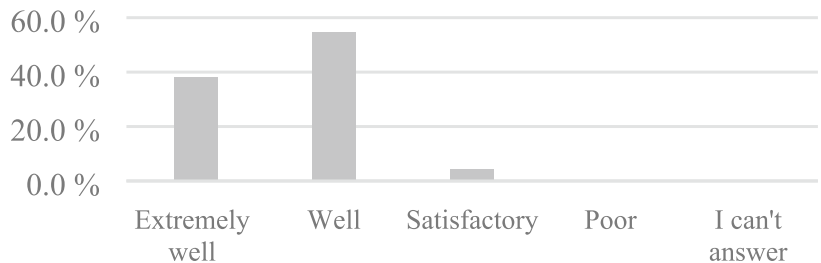

Fig. 2 The correspondence between workshops and a musician's work

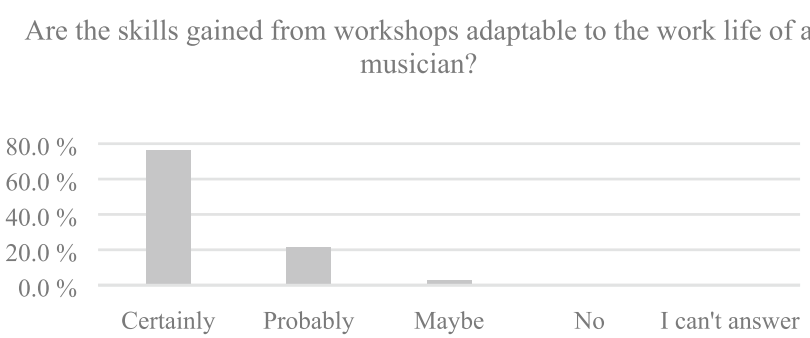

Fig. 3 The adaptability of the competence gained in workshops to a musician's work

I learnt more and more to listen to the others and appreciate the others' input in the band. The workshop started many ideas which I can develop in my playing. I think that the workshop was very essential from the viewpoint of my professional career. It was just what musicians' work life is like: planning, training and getting along with each other. (A15)

The last mentioned viewpoint appears also in the answers to the multiple-choice question, "How did the workshop correspond to your idea of the musician's work?" The students explained that the workshop work did correspond significantly to the musician'swork (see Fig. 2). In 38.2\% of the answers the correspondence was "extremely well," in 57.4\% "well," and in 4.4\% "satisfactory." None of the respondents answered that the correspondence was "poor", or "I can't answer".

According to the answers to the multiple-choice question, "Are the skills gained from workshops adaptable to the work life of a musician?" the competence gained in workshops was adaptable to the musician's work life "certainly" in 76.1\%, "probably" in 21.3\%, and "maybe" in 2,6\% of the answers. There were no answers telling "No" and "I can't answer". The finding is noteworthy (see Fig. 3), since, from the view of learning motivation development, the learner must appreciate and believe in the importance of the activities (e.g. Lehmann et al. 2007).

The work of a competent musician was not supported $(f=15, \mathrm{f} \%=4.4 \%)$ if the timetable was too tight or the student was uninformed about the repertoire to be played. Too demanding a repertoire caused feelings of uncertainty.

(Preliminary information about the repertoire) was scanty, but perhaps not enough.

E.g. the choices of pieces could have been different if there had been more informa- 
tion on them. A lot of knowledge was shared, however, during the workshop itself. (A11)

I could have been more courageous and thrown myself into interpretation better. The lack of techniques, however, took over my thoughts and I was sometimes very uncertain. (A19)

We could perhaps have thought more about playing the solo choruses together. Or perhaps I could have done so myself. On the other hand, it might have been a limiting factor (...). (A36)

\section{Relatedness in workshop learning}

In the written expressions of the development of relatedness to the music community $(f=59, \mathrm{f} \%=17.3 \%)$, the students referred to the positive influence of the professional musician when working and expressed the joy of successful action during a demanding work task.

(Working was) very rewarding. In the presence of a skilled professional, you feel how your own relation to jazz and other music like that gets deepened. Working is motivating. (A3)

In the beginning, the project felt insurmountable due to the challenging pieces that happened to fall on me. (...) Now, afterwards, it is easy to smile at all that wailing and teeth clamping. I did it! (A22)

The gig was successful to my mind and the audience sounded pleased, too. The joy of playing and singing shone from all members of the band. And the atmosphere was really good. :) (A32)

The expression of non-supported relatedness to the music community $(f=1,0.3 \%)$ was connected to the view that giving only one performance was inadequate in terms of describing the reality of work life. He/she wanted to have more gigs.

When the workshops are arranged, more performances should be organized one after another $=>$ A TOUR: it would resemble "real life". (A8)

\section{Discussion}

The task of this case study was to explore how the cooperation between popular and jazz music students and professional musicians in the music workshops in the Conservatory of Oulu in Finland was connected to the students' learning motivation from the perspective of SDT.

According to the answers to multiple-choice questions, workshop work corresponds to musician's work and the skills gained from it are adaptable to the work life of a musician. The students' $(N=62)$ written expressions $(F=341)$ revealed that 
working with a professional musician supported autonomy, competence and relatedness according to SDT in $88.6 \%(f=302)$ of responses. Non-supported autonomy, competence and relatedness were represented in $11.4 \%(f=39)$ of the answers.

The key SDT theme of learner autonomy was confirmed by the students' strong attachment to the workshop work early in the planning phase. The students took on a critical role by creating and implementing the artistic content for the performances (see Evans et al. 2013, p. 614). In the workshops, learning autonomy was realized as a chance to decide about things autonomously and, on the other hand, cooperatively with the others in the group (see Evans 2015), which is a typical feature of learning popular and jazz music (e.g. Green 2006; Lebler 2007). Making music according to the style in question is a social process in which the mutual interaction of musicians has the utmost importance in terms of achieving an artistic result (Berliner 1994; Gatien 2009; Gridley 2003).

Increasing autonomy was connected to the development of students' competence. Students were committed to acting according to the demands of the performance project and strived for the best in their own playing. One student (A23) stated: "I went through the challenges to victory, and it felt really fine. I learnt again to believe in my abilities throughout the workshop." Competence was viewed as a feeling of being capable of attaining things that one wants to attain and knows how to attain (e.g. Deci et al. 1991).

The professional musician's encouraging scaffolding in the workshop had a significant role for students' development (e.g. Küpers et al. 2014). The communication between the students and the professional musician was not only verbal, the students could also adopt action models that were starting points for imitating and making personal decisions. The professional musician guided the students by his/her doing towards artistically competent playing and acting as musicians. The students were given responsibility as soloists and accompanists when the process of growing to become members of the music community proceeded and the relatedness was strengthened. When a student feels competent to cooperate with a professional musician, his/her experience of belonging to musicians' community reinforces (see Coker 1989; Deci and Ryan 1985, 2000, 2014; Reeve 2004; Reeve et al. 2012). The finding is significant because, based on the previous research, the meaningfulness and usefulness of the activity has a positive effect on the student's motivation to learn (e.g. Cogdill 2014; Countryman 2014; Lehmann et al. 2007; Pajares 2012; Wigfield et al. 2012).

A central feature of SDT is its focus on the amount and form of external control (see e.g. Küpers et al. 2014; Reeve et al. 2012). Can we conclude - based on this research - that in the workshop there was only minimal external control? Don't the defined task (the performance) and the deadlines connected to it involve many necessary operations, and the evaluation of the outcomes attained (cf. Schaffner and Schiefele 2007)? Deci and Ryan (1985) emphasize that controlling learning does not necessarily mean non-supported autonomy. Although controlling learning has been found to be connected to a decrease in student motivation, it does not necessarily come about if the external control does not thwart learner autonomy (Radel et al. 2013, p. 101). According to Soenens et al. (2007), action that prevents autonomy gives students very few opportunities to make choices, does not support student initiative and does not justify external control. 


\section{Conclusion-implications for music education}

Learning a musician's skills by working together with a professional musician is not a new concept, as it is a centuries-long tradition (see Burwell 2012; Callaghan et al. 2012). In music institutions, many kinds of master classes and instrumental clinics are organized. In them, a visiting professional musician shows his/her skills and gives certain chosen students feedback on their music-making (Long et al. 2014). The difference between a traditional master class and the workshop method employed in this research is in the activation of students, their interaction and their reflection, as well as in the role of the professional musician (Green 2001, 2008).

The professional musician does not act distinctly as a teacher during the workshop, but as a peer musician. This way of acting had a noticeable influence on collaboration. In the beginning, the musician was perhaps expected to give detailed advice and to control the students' learning. When it did not happen, the students became activated, they started to ask questions themselves and to reflect on the issues. The musician's role in relation to the students seemed to be (judging by the results) one of an encouraging supervisor, a facilitator of learning and a partner.

In some workshops, student motivation did not develop into the best possible. The most emerged reason was that the students did not participate in planning. The consequence was uncertainty surrounding the theme of the workshop, the necessary preparations, timetables, repertoire to be played, tasks and the goals. According to the student responses, they regarded it as very meaningful to be allowed to participate in the workshop planning, to contribute to its implementation and apply to their own learning. The teacher who is responsible for the workshop has an important task when coordinating the action. Not all the teachers participating in this research had fully internalized the functional aspect of the workshops. In these cases, the students' tasks only involved being present at given times and being prepared to play, which did not align with the original concept of the workshop method.

The author acknowledges the limitations of a small sample case study. Then again, the value of such studies is their closeness to real-life situations and, in this particular case, to a musician's work (see Flyvbjerg 2006, p. 223). The purpose of learning at work is to provide with students learning experiences in authentic work situations (e.g. FNAE [Finnish National Agency for Education] 2014). The typical work of a popular and jazz musician involves versatile tasks, more than just playing the instrument, and this aspect is significant to be incorporated into the educational setting (Berliner 1994; Coker 1989; Green 2001).

The present research (also Burwell 2012, p. 284; Evans 2015, p. 77-79; Gatien 2009, 96; Lebler 2007, p. 207-208) suggests that, in music education institutes, learning environments should be developed in which the musician's work can be confronted and experienced: the students should (1) plan and implement performances, (2) critically evaluate the learning process and the results attained from it, and (3) work in cooperation with professional musicians. In all phases, the student has a key role to play such that his/her experiences of autonomy, competence and relatedness are satisfied. 


\section{Authors' contributions}

EV carried out the study of motivational characteristics in vocational music education and drafted the manuscript. The author read and approved the final manuscript.

\section{Funding}

Part of the research project has been implemented by utilising The Finnish Cultural Foundation's science grant.

\section{Availability of data and materials}

All of the used data is available for further research. At this moment data is filed in paper form but could be scanned and sheared out.

\section{Competing interests}

Not applicable.

Received: 8 May 2020 Accepted: 30 October 2020

Published online: 12 November 2020

\section{References}

Barrett MS, Bond N (2014) Connecting through music: the contribution of a music programme to fostering positive youth development. Res Stud Music Educ 37(1):37-54

Berliner P (1994) Thinking in jazz: the infinite art of improvisation. University of Chicago Press, Chicago

Burwell K (2012) Apprenticeship in music: a contextual study for instrumental teaching and learning. Int J Music Educ 31(3):276-291

Callaghan J, Emmons S, Popeil L (2012) Solo voice pedagogy. In: McPherson GE, Welch GF (eds) The Oxford handbook of music education, vol 1. Oxford University Press, Oxford, pp 559-580

Cogdill SH (2014) Applying research in motivation and learning to music education: what the experts say update. Appl Res Music Educ 33(2):49-57

Cohen L, Manion L, Morrison K (2007) Research methods in education, 6th edn. Routledge, London

Coker J (1989) Teaching of jazz. Prentice Hall, Englewood Cliffs

Countryman J (2014) Missteps, flaws and morphings in children's musical play: snapshots from school playgrounds. Res Stud Music Educ 36(1):3-18

Creswell JW, Plano Clark VL (2011) Designing and conducting mixed methods research, 2nd edn. Sage Publications, London

Deci E, Ryan R (1985) The general causality orientations scale: self-determination in personality. J Res Pers 19(2):109-134

Deci E, Ryan R (2000) The "what" and "why" of goal pursuits: human needs and the self-determination of behavior. Psychol Inq 11(4):227-268

Deci E, Ryan R (2014) The importance of universal psychological needs for under-standing motivation in the workplace. In: Gagné M (ed) The Oxford handbook of work engagement, motivation, and self-determination theory. Oxford University Press, Oxford, pp 13-32

Deci E, Ryan R (2017) Self-Determination Theory. Basic psychological needs in motivation, development, and wellness. Guildford Press, New York

Deci EL, Vallerand RJ, Pelletier LG, Ryan RM (1991) Motivation and education: the self-determination perspective. Educ Psychol 26(3):325-346

Evans P (2015) Self-determination theory: an approach to motivation in music education. Musicae Scientiae 19(1):65-83

Evans P, Bonneville-Roussy A (2016) Self-determined motivation for practice in university music students. Psychol Music 44(5):1095-1110

Evans P, McPherson GE, Davidson JW (2013) The role of psychological needs in ceasing music and music learning activities. Psychol Music 41(5):600-619

Flyvbjerg B (2006) Five misunderstandings about case-study research. Qual Inquiry 12(2):219-245

FNAE [Finnish National Agency for Education] (2014) Musiikkialan perustutkinto [Vocational qualification in music]. OPH, Helsinki

Gatien G (2009) Categories and music transmission. Action Crit Theory Music Educ 8(2):94-119

Gaunt H (2011) Understanding the one-to-one relationship in instrumental/vocal tuition in higher education: comparing student and teacher perceptions. Br J Music Educ 28:159-179

Gonzalez-Moreno PA (2012) Student motivation in graduate music programmes: an examination of personal and environmental factors. Music Educ Res 14(1):79-102

Green L (2001) How popular musicians learn: a way ahead for music education. Ashgate, London

Green L (2006) Popular music education in and for itself, and for "other" music: current research in the classroom. Int J Music Educ 24(2):101-118

Green L (2008) Music, informal learning and the school: a new classroom pedagogy. Ashgate, Aldershot

Gridley M (2003) Jazz styles: history and analysis, 8th edn. Prentice Hall, New Jersey

Grow GO (1991) Teaching learners to be self-directed. Adult Educ Q 41(3):125-149

Hallam S (2009) Motivation to learn. In: Hallam S, Cross I, Thaut M (eds) Handbook of psychology of music. Oxford University Press, Oxford, pp 285-294

Hallam S (2011) What predicts level of expertise attained, quality of performance, and future musical aspirations in young instrumental players? Psychol Music 41(3):267-291

Jokinen J, Lähteenmäki L, Nokelainen P (2009) Työssäoppimisen lumo [The magic of on-the-job learning]. HAMK, Hämeenlinna 
Küpers E, van Dijk M, McPherson G, van Geert P (2014) A dynamic mode that links skill acquisition with self-determination in instrumental music lessons. Musicae Scientiae 18(1):17-34

Lam CF, Gurland ST (2008) Self-determined work motivation predicts job out-comes, but what predicts self-determined work motivation? J Res Pers 42:1109-1115

Lebler D (2007) Student-as-master? Reflections on a learning innovation in popular mu-sic pedagogy. Int J Music Educ 25(3):205-221

Lehmann AC, Sloboda JA, Woody RH (2007) Psychology for musicians: understanding and acquiring the skills. Oxford University Press, New York

Leung BW, McPherson GE (2011) Case studies of factors affecting the motivation of musical high achievers to learn music in Hong Kong. Music Educ Res 13(1):69-91

Long M, Creech A, Gaunt H, Hallam S (2014) Conservatoire students' experiences and perceptions of instrument-specific master classes. Music Educ Res 16(2):176-192

Maclntyre PD, Schnare B, Ross J (2018) Self-determination theory and motivation for music. Psychol Music 46(5):699-715

Marshall C, Rossman GB (2011) Designing qualitative research. SAGE Publications, Thousand Oaks

Nissilä S-P, Virkkula E (2015) Problem solution processes of musicians and engineers: what do their approaches look like? J Prob Based Learn Higher Educ 3(1):96-115

Pajares F (2012) Motivational role of self-efficacy beliefs in self-regulated learning. In: Schunk DH, Zimmerman BJ (eds) Motivation and self-regulated learning. Theory, research and applications. Routledge, New York, pp 111-140

Pintrich PR (2003) A motivational science perspective on the role of student motivation in learning and teaching contexts. J Educ Psychol 95:667-686

Pintrich PR, Schunk DH (2002) Motivation in education: Theory, research, and applications, 2nd edn. Prentice Hall, Upper Saddle River

Radel R, Pelletier L, Baxter D, Fournier M, Sarrazin P (2013) The paradoxical effect of controlling context on intrinsic motivation in another activity. Learn Instr 29:95-102

Reeve J (2004) Self-determination theory applied to educational settings. In: Deci EL, Ryan RM (eds) Handbook of selfdetermination research. University of Rochester Press, Rochester, pp 183-204

Reeve J, Ryan RM, Deci EL, Jang H (2012) Understanding and promoting autonomous self-regulation: A self-determination theory perspective. In: Schunk DH, Zimmerman BJ (eds) Motivation and self-regulated learning. Theory, research and applications. Routledge, New York, pp 223-244

Renwick JM, Reeve J (2012) Supporting motivation in music education. In: McPherson GE, Welch GF (eds) The Oxford handbook of music education, vol 1. Oxford University Press, Oxford, pp 559-580

Roca JC, Gagné M (2008) Understanding e-learning continuance intention in the workplace: a self-determination theory perspective. Comput Hum Behav 24:1585-1604

Schaffner E, Schiefele U (2007) The effect of experimental manipulation of student motivation on the situational representation of text. Learn Instr 17:755-772

Schreier M (2012) Qualitative content analysis in practice. SAGE Publications, Thousand Oaks

Soenens B, Vansteenkiste M, Lens W, Luyckx K, Goossens L, Beyers W, Ryan RM (2007) Conceptualizing parental autonomy support: adolescent perceptions of promoting independence versus promoting volitional functioning. Dev Psychol 43(3):633-646

Stake R (1995) The art of case research. SAGE Publications, Thousand Oaks

Swanborn P (2010) Case study research: what, why and how?. Sage Publications, London

Teddlie C, Tashakkori A (2011) Mixed methods research. Contemporary issues in an emerging field. In: Denzin NK, Lincoln YS (eds) The SAGE handbook of qualitative research. SAGE Publications, Thousand Oaks, pp 285-300

Virkkula E (2016a) Communities of Practice in the Conservatory: learning with a professional musician. Br J Music Educ $33(1): 27-42$

Virkkula E (2016b) Informal in formal: the relationship of informal and formal learning in popular and jazz music master workshops in conservatoires. Int J Music Educ 34(2):171-185

Virkkula E, Nissilä S-P (2014) In-service teachers' learning through integrating theory and practice. SAGE Open J 4(4):1-8

Virkkula E, Nissilä S-P (2017) Towards Professionalism in Music: self-assessed learning strategies of conservatory music students. CEPS-J 7(3):113-133

Wigfield A, Cambria J (2010) Students' achievement values, goal orientations and interest: definitions, development, and relations to achievement outcomes. Dev Rev 30(1):1-35

Wigfield A, Hoa LW, Klauda SL (2012) The role of achievement values in the regulation of achievement behaviours. In: Schunk DH, Zimmerman BJ (eds) Motivation and self-regulated learning. Theory, research and applications. Routledge, New York, pp 169-196

Yin RK (2013) Case study research: design and methods, 5th edn. Sage Publications, Thousand Oaks

\section{Publisher's Note}

Springer Nature remains neutral with regard to jurisdictional claims in published maps and institutional affiliations. 